DOI: https://doi.org/10.32839/2304-5809/2019-12-76-73

УДК 342.336 .1

Мельник B.I., Андрющенко O.В.

Сумський державний університет

\title{
НОРМАТИВНО-ПРАВОВЕ РЕГУЛЮВАННЯ ЕКОНОМІЧНОЇ БЕЗПЕКИ
}

\begin{abstract}
Анотація. Статтю присвячено дослідженню поняття «економічна безпека» та нормативно-правового регулювання забезпечення економічної безпеки України. Визначено систему нормативно-правових актів, якими здійснюеться правове регулювання економічної безпеки. Встановлено, що на теперішній час діюче законодавче України не містить поняття «економічна безпека". Внаслідок цього існують різні наукові підходи до розуміння та тлумачення змісту поняття «економічна безпека». З'ясовано, що основним нормативно-правовим актом, яким врегульовуеться досліджуване питання, є Закон України «Про національну безпеку України». При цьому, зазначений Закон не визначає поняття «економічна безпека», але його норми містять визначення «фінансово-економічні можливості держави». Тобто, поняття «економічна безпека» є складовим елементом поняття «національна безпека».
\end{abstract}

Ключові слова: економічна безпека, національні інтереси, Рада національної безпеки і оборони України, політика національної безпеки, стратегія національної безпеки.

Melnyk Vadym, Andriushchenko Oleksandr Sumy State University

\section{LEGAL REGULATION OF ECONOMIC SECURITY}

Summary. The article is devoted to the study of the concept of "economic security" and regulation of ensuring the economic security of Ukraine. At present, current legislation of Ukraine does not contain the concept of "economic security". As a result, there are different scientific approaches to understanding and interpreting the notion of "economic security". Depending on the direction of the research vector, scientists discover the essence of economic security based on economic or legal categories. The system of normative legal acts, which carry out legal regulation of economic security, is defined. The Law of Ukraine "On National Security of Ukraine" refers to the fundamental national interests of Ukraine: sustainable development of the national economy, civil society, the state to ensure the growth of the standard and quality of life of the population, integration of Ukraine into the European political, economic, security, legal space, membership in the European Union and the North Atlantic Treaty Organization, the development of mutually beneficial relations with other countries. The Decree of the President of Ukraine "On the decision of the National Security and Defense Council of Ukraine of May 6, 2015 "The National Security Strategy of Ukraine" plays an important role in the sphere of economic security of Ukraine". The General Provisions of the Strategy provide that the National Security Policy of Ukraine is based on respect for the rules and principles of international law. Protection of such values should be provided by the Armed Forces of Ukraine, other military formations formed in accordance with the laws of Ukraine, intelligence, counterintelligence and law enforcement agencies of the state, dynamic development of the economy of Ukraine. It is established that the current legislation of Ukraine does not contain the concept of "economic security". As a result, there are different scientific approaches to understanding and interpreting the meaning of "economic security". It has been found that the main legal act regulating the investigated issue is the Law of Ukraine "On National Security of Ukraine". However, the said Law does not define the concept of "economic security", but its rules contain the definition of "financial and economic opportunities of the state". That is, the concept of "economic security" is an integral part of the concept of "national security"

Keywords: economic security, national interests, National Security and Defense Council of Ukraine, national security policy, national security strategy.

Постановка проблеми. На сьогодні перед нашою країною постало ряд завдань, від вирішення яких залежать подальший соціальноекономічний розвиток держави, успішна реалізація розпочатих редрорм та завершення процесу евроінтеграції. Серед таких завдань важливе місце посідає забезпечення економічної безпеки України, так як саме захищеність інтересів держави у економічній сорері від внутрішніх та зовнішніх протиправних посягань дозволяе їй повноцінно виконувати свої зобов'язання перед своїми громадянами й міжнародною спільнотою. Економічна безпека держави повинна забезпечуватися дієвими адміністративно-правовими засобами, які мають бути законодавчо врегульовані та закріплені в нормативно-правових актах нашої держави.

Вивчення структури та змісту економічної безпеки, різних концепцій і стратегій її забезпечення дозволяє комплексно дослідити механізм адміністративно-правового регулювання в цій copepi, окреслити коло суб'єктів, що здійснюють адміністративно-правове регулювання забезпечення економічної безпеки, виявити проблемні аспекти національного адміністративно-правового регулювання щодо забезпечення економічної безпеки України та знайти шляхи їх вирішення. Це є необхідним, оскільки наразі в Україні ще не розроблена єдина державна політика у сорері забезпечення економічної безпеки, відсутня повноцінна система забезпечення економічної безпеки, недостатньо розвинута взаємодія між суб'єктами забезпечення економічної безпеки країни. Наукова та практична значущість вирішення зазначених проблем зумовлюе актуальність їх дослідження у даному магістерському дослідженні.

Аналіз останніх досліджень і публікацій. Питання адміністративно-правового забезпечення економічної безпеки є об'єктом наукової уваги 
багатьох дослідників, таких як: О.О. Бригінець, Ю.І. Аністратенко, О.В. Батраченко, Д.В. Власенко, Д.О. Гетманцев, В.А. Глуховеря, Д.К. Катрич, А.Т. Комзюк, Т.О. Коломоєць, А.М. Куліш, O.M. Музичук, Р.В. Олійник, О.М. Резнік, О.В. Пономарьов, В.О. Поярков, С.В. Чумаченко, C.C. Шоптенко, І.Г. Фурман, О.М. Юрченко та ін.

Мета статті. Мета статті полягає у розкритті особливостей нормативно-правового регулювання забезпечення економічної безпеки України.

Виклад основного матеріалу. На теперішній час, діюче законодавче України не містить поняття «економічна безпека». Внаслідок цього існують різні наукові підходи до розуміння та тлумачення змісту поняття «економічна безпека». Залежно від спрямованості вектору наукових досліджень, науковці розкривають сутність економічної безпеки грунтуючись на економічних або юридичних категоріях. Як правило, науковці-правознавці тлумачать економічну безпеку, виходячи зі змісту таких категорій як «безпека" та "національна безпека" [1, с. 92-95].

3 цього приводу необхідно звернути увагу на норми Закону України «Про національну безпеку України» від 21.06.2018 № 2469-VIII (далі - Закон). Пункт 9 частини 1 статті 1 Закону містить поняття "національна безпека України» - захищеність державного суверенітету, територіальної цілісності, демократичного конституційного ладу та інших національних інтересів України від реальних та потенційних загроз та поняття «національні інтереси України» - життево важливі інтереси людини, суспільства і держави, реалізація яких забезпечує державний суверенітет України, їі прогресивний демократичний роз виток, а також безпечні умови життедіяльності i добробут їі громадян [2]. Зазначимо, що Закон не визначає поняття "економічна безпека». У нормах Закону міститься визначення «фінансово-економічні можливості держави». Тобто, поняття «економічна безпека» є складовим елементом поняття «національна безпека». Це свідчить про недостатню увагу законодавця до питання економічної безпеки як складового елемента національної безпеки та нащіональних економічних інтересів України. Закон фокусуе увагу на питаннях національної безпеки з точки зору оборони. Але при цьму зазначається що обороні та безпекові заходи здійснюються виходячи 3 dpiнансово-економічних можливостей держави.

Надалі, норми частини 3-4 статті 3 Закону відносять до фрундаментальних національних інтересів України сталий розвиток національної економіки, громадянського суспільства, держави для забезпечення зростання рівня та якості життя населення, інтеграцію України до европейського політичного, економічного, безпекового, правового простору, набуття членства в Свропейському Союзі та Організації Північноатлантичного договору, розвиток рівноправних взаємовигідних відносин з іншими державами. Державна політика у сфрерах національної безпеки і оборони спрямовується на забезпечення воєнної, зовнішньополітичної, державної, економічної, інформаційної, екологічної безпеки, кібербезпеки України тощо. Отже, зміст вищезазначених норм Закону свідчить про намір держави забезпечити економічну безпеку держави шляхом інтеграції до европейського економічного простору та північноатлантичного альянсу [2].

Необхідно зауважити, Закон не містить норм що врегульовують питання компетенції державних органів відповідальних за економічну безпеку на стратегічному рівні. Норма статті 14 Закону врегульовуе тільки питання координації у сфрерах національної безпеки і оборони. Норми статті визначають що в умовах воєнного або надзвичайного стану, в особливий період, а також у разі виникнення кризових ситуацій, що загрожують національній безпеці України, Рада національної безпеки і оборони України координуе діяльність органів виконавчої влади, розглядає пропозищії щодо застосування відповідно до закону спещіальних економічних та інших обмежувальних заходів. Норма статті 19 Закону врегульовує що Служба безпеки України є контррозвідувальний захист державного суверенітету, конституційного ладу і територіальної цілісності, оборонного і науково-технічного потенціалу, кібербезпеки, економічної та інфрормащійної безпеки держави, об'єктів критичної інфраструктури.

Важливу роль у сорері економічної безпеки України в умовах сьогодення має Указ Президента України «Про рішення Ради нащіональної безпеки і оборони України від 6 травня 2015 року «Про Стратегію національної безпеки України»" (далі - Стратегія) [3]. У Загальних положеннях Стратегії передбачено, що Політика національної безпеки України грунтуеться на повазі до норм і принципів міжнародного права. Україна захищатиме свої фрундаментальні цінності, визначені Конституцією та законами України, незалежність, територіальну цілісність і суверенітет, гідність, демократію, людину, їі права і свободи, верховенство права, забезпечення добробуту, мир та безпеку. Захист вищевказаних цінностей повинні забезпечити Збройні Сили України, інші військові фрормування, утворені відповідно до законів України, розвідувальні, контррозвідувальні і правоохоронні органи держави, динамічний розвиток економіки України.

Однією із основних цілей Стратегії, передбачених ст. 2, є забезпечення економічного, соціального і гуманітарного розвитку. Такий розвиток законодавець вбачає у забезпечення інтеграції України до европейського економічного простору та dpopмуванні умов для вступу до північноатлантичного альянсу. Досягнення визначених цілей, 3 точки зору досягнення належного рівня економічної безпеки, потребує: зміцнення соціально-економічного розвитку України, якісно нової державної політики, спрямованої на ефективний захист національних інтересів в економічній, сорері, комплексного редрормування системи забезпечення нащіональної безпеки, нового зовнішньополітичного позиціонування України у світі в умовах нестабільності глобальної системи безпеки [3].

Стратегія враховує актуальні загрози національній безпеці У країни. У першу чергу мова йде про агресивні дії Російської федеращії, що здійснюються для 3 метою виснаження української економіки та підриву суспільно-політичної стабільності. Такі агресивні дії вчиняються шляхом:

- блокування зусиль України щодо протидії монополізації стратегічних галузей національної економіки російським капіталом; 
- залежності від монопольних постачань енергетичних ресурсів;

- ведення торговельно-економічної війни тощо.

До загроз у сорері нащіональної безпеки, економічної зокрема, Стратегія відноситись неедективність системи забезпечення нащіональної безпеки і оборони України:

- несдормованість сектору безпеки і оборони України як цілісного функціонального об'єднання, керованого з єдиного центру;

- інституційна слабкість, непрофресійність, структурна незбалансованість органів сектору безпеки і оборони;

- недостатність ресурсного забезпечення та неедективне використання ресурсів у секторі безпеки і оборони;

- відсутність едективних зовнішніх гарантій безпеки України тощо.

До економічних загроз Стратегія відносить економічну кризу, виснаження фінансових ресурсів держави, зниження рівня життя населення що проявляеться у наступному:

- монопольно-олігархічна, низькотехнологічна, ресурсовитратна економічна модель;

- відсутність чітко визначених стратегічних цілей, пріоритетних напрямів і завдань соціально-економічного, воєнно-економічного та науково-технічного розвитку України, а також едективних механізмів концентрації ресурсів для досягнення таких цілей;

- високий рівень «тінізації» та криміналізації національної економіки, кримінально-кланова система розподілу суспільних ресурсів;

- деформоване державне регулювання і корупційний тиск на бізнес;

- надмірна залежність національної економіки від зовнішніх ринків;

- неефективне управління державним боргом;

- зменшення добробуту домогосподарств та зростання рівня безробіття;

- активізація міграційних процесів унаслідок бойових дій;

- руйнування економіки та систем життезабезпечення на тимчасово окупованих територіях, втрата їх людського потенціалу, незаконне вивезення виробничих фондів на територію Росії.

При цьому, законодавець не визначає відповідальний державний орган у сфері економічної безпеки, не розробляе програму протидії загрозам, не забезпечує належне фрінансування заходів про- тидії загрозам. До організащійних кроків у сорері економічної безпеки Стратегія відносить редормування розвідувальних, контррозвідувальних i правоохоронних органів. Таке реформування має на меті створення динамічної, укомплектованої високопрофресійними фрахівцями, забезпеченої сучасними матеріальними і технічними засобами спеціальної служби, здатної ефрективно захищати економічної безпеки зокрема.

Також, важливим аспектом економічної безпеки України Стратегія визначає інтеграцію до європейського економічного простору та північноатлантичного альянсу. Тому варто звернути увагу на Угоду про асоціацію між Україною і СС. Положення Угоди визначають стратегічні орієнтири проведення системних політичних і соціально-економічних редрорм в Україні, широкомасштабної адаптації законодавства України до норм і правил Європейського Союзу. Пріоритетом $\epsilon$ фрормування ключових передумов, необхідних для набуття Україною членства в Свропейському Союзі як гарантії демократичного розвитку, економічного добробуту та зміџнення безпеки [4].

Висновки. Норми Закону України «Про національну безпеку України» від 21.06.2018 № 2469-VIII, Стратегія національної безпеки України від 26.05.2015 № 287/2015, Угода про асоціацію між Україною та Свропейським Союзом від 27.06.2014 та інші нормативно-правові акти не містять окремого поняття «економічна безпека». Вказане поняття є складовим елементом поняття «національна безпека». Категорія економічна безпека нормами законодавства врегульована фррагментарно. При цьому, органи державної влади, здійснюючи свої повноваження, забезпечують лише певний спектр економічної безпеки держави (митна, податкова, бюджетна тощо). Це свідчить про відсутність единого державного органу що фороме та здійснюе забезпечення економічної безпеки держави. При цьому, значні сподівання у сорері економічної безпеки законодавець покладає на інтеграцію до европейського економічного простору та північноатлантичного альянсу. У загальному підсумку, широке розуміння категорії економічної безпеки призводить до різного розуміння науковцями даного поняття, що в свою чергу, зумовлює необхідність подальших наукових досліджень в цьому напряму та законодавчого врегулювання правовідносин забезпечення економічної безпеки держави.

\section{Список літератури:}

1. Резник О.Н. Экономическая безопасность как составляющая национальной безопасности Украины, которая охраняет финансовую систему Украины. Legea si viata (Закон и жизнь). 2016. № 11. С. 92-95.

2. Про національну безпеку України : Закон України від 21.06.2018 № 2469-VIII / Верховна Рада України. URL: https://zakon.rada.gov.ua/laws/show/2469-19\#n107 (дата звернення: 20.11.2019).

3. Про рішення Ради національної безпеки і оборони України від 6 травня 2015 року «Про Стратегію національної безпеки України» : Указ Президента України від 26.05.2015 № 287/2015 / Президент України. URL: https://zakon.rada.gov.ua/laws/show/287/2015 (дата звернення: 20.11.2019).

4. Угода про асоціацію між Україною, з однієї сторони, та Свропейським Союзом, Свропейським співтовариством з атомної енергії і їхніми державами-членами, з іншої сторони: Угоду ратифріковано із заявою Законом № 1678-VII від 16.09.2014 / Верховна Рада України. URL: https://zakon3.rada.gov.ua/laws/show/984_011 (дата звернення: 20.11.2019).

\section{References:}

1. Reznik, O.N. (2016). Ekonomicheskaya bezopasnost kak sostavlyayushchaya nacionalnoj bezopasnosti Ukrainy, kotoraya ohranyaet finansovuyu sistemu Ukrainy [Economic security as a component of national security of Ukraine, which protects the financial system of Ukraine]. Legea si viata (Zakon i zhizn), vol. 11, pp. 92-95. 
2. On National Security: Law of Ukraine dated 21.06.2018 № 2469-VIII // Verkhovna Rada of Ukraine. URL: https://zakon.rada.gov.ua/laws/show/2469-19\#n107 (accessed 20 November 2019).

3. Pro rishennya Radi natsonal'noi bezpeki oboroni Ukrani vid 6 travnya 2015 roku "Pro Strategiyu natsíonal'noi bezpeki Ukraini” víd 26 travnya 2015 roku № 287/2015 [The Decree of the President of Ukraine "About the decision of The National Security and Defense Council of Ukraine on the 6th of May 2015" About the National Security Strategy of Ukraine " of 26 May 2015 № 287/2015]. URL: https://zakon.rada.gov.ua/laws/show/287/2015 (accessed 20 November 2019).

4. Association Agreement between the European Union and its Member States, of the one part, and Ukraine, of the other part OJ L 161, 29.05.2014, p. 3-2137. URL: https://eurlex.europa.eu/legalcontent/EN/ ALL/?uri=CELEX\%3A22014A0529\%2801\%29 